\title{
A new charge-tagged proline-based organocatalyst for mechanistic studies using electrospray mass spectrometry
}

\author{
J. Alexander Willms, Rita Beel, Martin L. Schmidt, Christian Mundt \\ and Marianne Engeser ${ }^{*}$
}

\author{
Full Research Paper \\ Address: \\ University of Bonn, Kekulé-Institute of Organic Chemistry and \\ Biochemistry, Gerhard-Domagk-Str. 1, D-53121 Bonn, Germany \\ Email: \\ Marianne Engeser* - Marianne.Engeser@uni-bonn.de \\ * Corresponding author \\ Keywords: \\ charge tag; electrospray; mass spectrometry; organocatalysis; \\ proline; template
}

\author{
Beilstein J. Org. Chem. 2014, 10, 2027-2037. \\ doi:10.3762/bjoc. 10.211 \\ Received: 06 June 2014 \\ Accepted: 13 August 2014 \\ Published: 28 August 2014 \\ This article is part of the Thematic Series "Chemical templates". \\ Guest Editor: S. Höger \\ (c) 2014 Willms et al; licensee Beilstein-Institut. \\ License and terms: see end of document.
}

\begin{abstract}
A new 4-hydroxy-L-proline derivative with a charged 1-ethylpyridinium-4-phenoxy substituent has been synthesized with the aim of facilitating mechanistic studies of proline-catalyzed reactions by ESI mass spectrometry. The charged residue ensures a strongly enhanced ESI response compared to neutral unmodified proline. The connection by a rigid linker fixes the position of the charge tag far away from the catalytic center in order to avoid unwanted interactions. The use of a charged catalyst leads to significantly enhanced ESI signal abundances for every catalyst-derived species which are the ones of highest interest present in a reacting solution. The new charged proline catalyst has been tested in the direct asymmetric inverse aldol reaction between aldehydes and diethyl ketomalonate. Two intermediates in accordance with the List-Houk mechanism for enamine catalysis have been detected and characterized by gas-phase fragmentation. In addition, their temporal evolution has been followed using a microreactor continuous-flow technique.
\end{abstract}

\section{Introduction}

Electrospray ionization (ESI) mass spectrometry [1] has not only developed into a standard characterization method for an extremely broad variety of substances [2], but has also been recognized as a valuable tool for studying reaction mechanisms by transferring species of a reacting solution directly into the gas phase of a mass spectrometer [3-7]. The technique allows glimpses into the reacting solution as a function of time [8] and beyond that a characterization of transient intermediates by tandem mass spectrometry. ESI mass-spectrometric mechanistic studies have been reported for a broad range of reaction types ranging from transition metal-catalyzed polymerization [6,9] and coupling reactions [8,10-17] to purely organic Diels-Alder reactions $[18,19]$ to cite only a few representative examples. 
However, the detection of transient reactive species is often hindered by their very low concentration. A reacting solution of a catalytic transformation typically contains quite a number of different species. Side products, off-cycle resting states, reagent degradation products and impurities of various origins may be present in much higher concentration than the interesting reactive intermediates. Thus, ESI spectra of reacting solutions can be frustratingly complicated and the transient species of interest might be superposed with a large number of more intense background signals [20]. In quantification using ESI, the detection limit has been lowered significantly by selected ion monitoring in MS/MS mode [2]. Similarly, transient reactive species have been successfully extracted from the chemical noise by collision-induced dissociation (CID) MS/MS [20]. However, it is not possible to identify unknown or unexpected species by this strategy.

As a major drawback of ESI mass spectrometry in general, the signal intensity does not directly parallel the concentration, but the so called ESI response, i.e., the ionization probability during the ESI process [2,21]. Hence it happens that the reaction intermediates of interest are concealed by easily ionizable other compounds present in the reacting solution. A convenient approach to solve this problem is the use of covalently attached charge tags $[6,8,9,12,22,23]$. Charge-tagging the catalyst selectively enhances the signal abundances of all catalyst-derived species in a reacting solution and thus facilitates the identification of low-concentrated transient catalytic species. As a complementary approach, charge-tagged substrates have been used to easily identify ("fish for") efficient catalysts [6,9].

Since the year 2000, enantioselective catalysis based on small organic metal-free molecules has become an enormously growing research topic [24-30]. A large variety of organocatalyzed reactions with high efficiency and selectivity are nowadays known so that organocatalysis complements current catalytic fields such as organometallic or enzymatic catalysis as an independent subdomain [24-30]. Parallel to the enormous growth of organocatalytic applications in synthesis, mechanistic studies on organocatalytic reactions [31-38] using ESI mass spectrometry [20,39-49] have been reported. The pioneering studies of List and Barbas [50] revealed that the amino acid L-proline is an effective catalyst for a great variety of organic reactions, such as the direct asymmetric aldol reaction, one of the most important $\mathrm{C}-\mathrm{C}$ bond-forming reactions in organic synthesis [51]. The currently accepted mechanism suggests a central enamine intermediate which forms a Zimmerman-Traxler-like transition state with the acceptor substrate $[36,37]$. The activity and enantioselectivity achieved by proline in many cases is thought to be due to a templating effect of the $\mathrm{OH}$ group directing the aldehyde in a preferred position via hydrogen bonding [24,25]. It is still controversial whether oxazolidinone formation plays a pivotal role in the catalytic cycle or just serves as an rate limiting parasitic off-cycle equilibrium [31,33,35,52].

Thus, we aimed to synthesize a charge-tagged L-proline-based organocatalyst for mechanistic studies by ESIMS. Few proline derivatives carrying a covalently fixed charge have been reported by now $[43,53]$. They consist of an imidazolium salt attached to hydroxyproline via an ester group at the end of a flexible alkyl spacer. Interestingly, such charge tags can cause an enhancement of the catalytic performance through electrosteric activation [53], but backfolding can also alter and disturb the catalytic process and induce the formation of side products [43]. In order to fix the charge far away from the catalytic center and thus leave the original catalytic activity of L-proline preferably undisturbed, we chose a stiff 1-ethylpyridinium unit as charge-carrier separated from the catalytic center by a rigid phenyl linker (Figure 1).

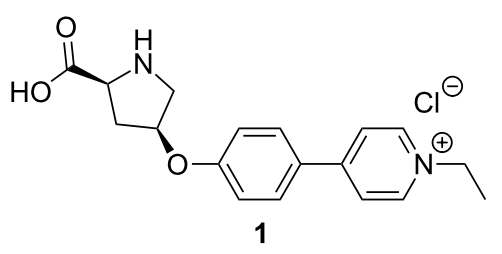

Figure 1: The new charge-tagged proline-derived catalyst 1.

We then tested the applicability of $\mathbf{1}$ for ESIMS mechanistic studies on the first "inverse" crossed aldol reaction (Scheme 1) published in 2002 by Jørgensen and coworkers [54] in which the aldehyde acts as the donor in contrast to the "normal" crossed aldol mechanism. It represents an interesting version of a typical proline-catalyzed reaction for which, to the best of our knowledge, mechanistic studies have not been reported so far.

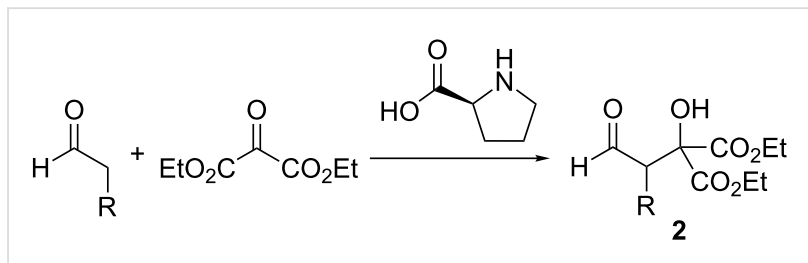

Scheme 1: Inverse aldol reaction with aldehyde donors according to Jørgensen [54]. We studied the reaction for $\mathrm{R}=\mathrm{Ph}$ (labelled a throughout this manuscript) and for $\mathrm{R}=\mathrm{Et}(\mathbf{b})$.

\section{Results and Discussion Synthesis}

Formation of the charge-carrying unit was accomplished starting from commercially available 4-bromophenol using a 
strategy reported by Diemer et al. [55]. Protection of the hydroxy group to yield 3 [56] was followed by Suzuki crosscoupling with commercial pyridine-4-boronic acid leading to 4 . Subsequent deprotection led to 4-(pyridine-4-yl)phenol (5) (Scheme 2) [55].

The preparation of the charge-tagged catalyst 1 starting from doubly-protected hydroxyproline 6 [57] is depicted in Scheme 3. To introduce a suitable leaving group for the following step of the synthesis, compound $\mathbf{6}$ was mesylated to give the derivative 7 [58] for which crystals suitable for X-ray analysis have been obtained (Figure 2). An $\mathrm{S}_{\mathrm{N}} 2$ reaction with 5 [55] led to $\mathbf{8}$. We abandoned our initial shorter synthetic route based on a Mitsunobu reaction leading from $\mathbf{6}$ directly to $\mathbf{8}$ due to severe purification difficulties. Compound $\mathbf{8}$ could be chargetagged to 9 using ethyl bromide. Finally, the free catalyst $\mathbf{1}$ was obtained by acidic deprotection [59].

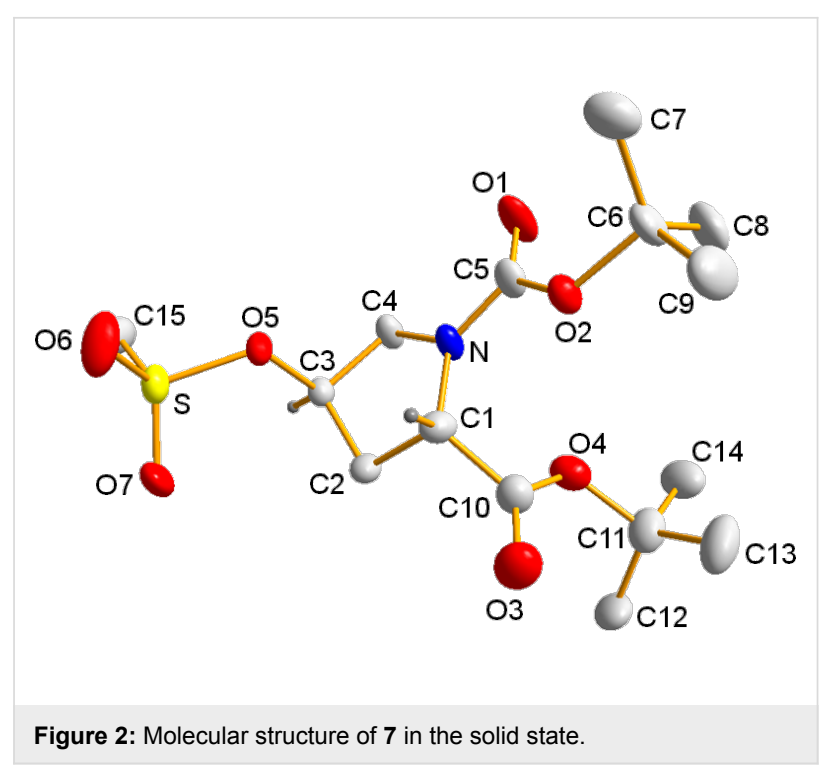

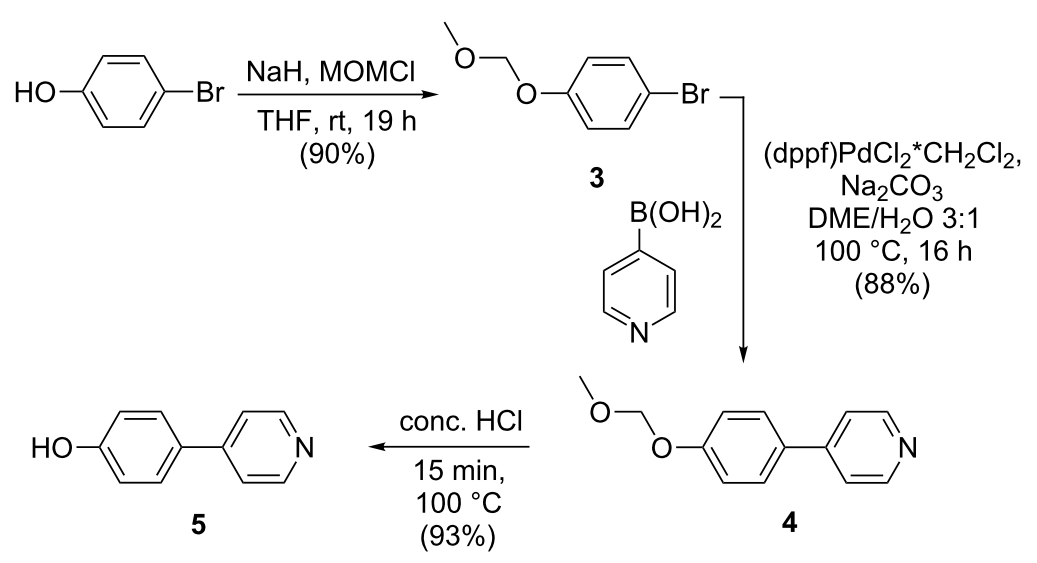

Scheme 2: Synthesis of 4-(pyridin-4-yl)phenol (5).
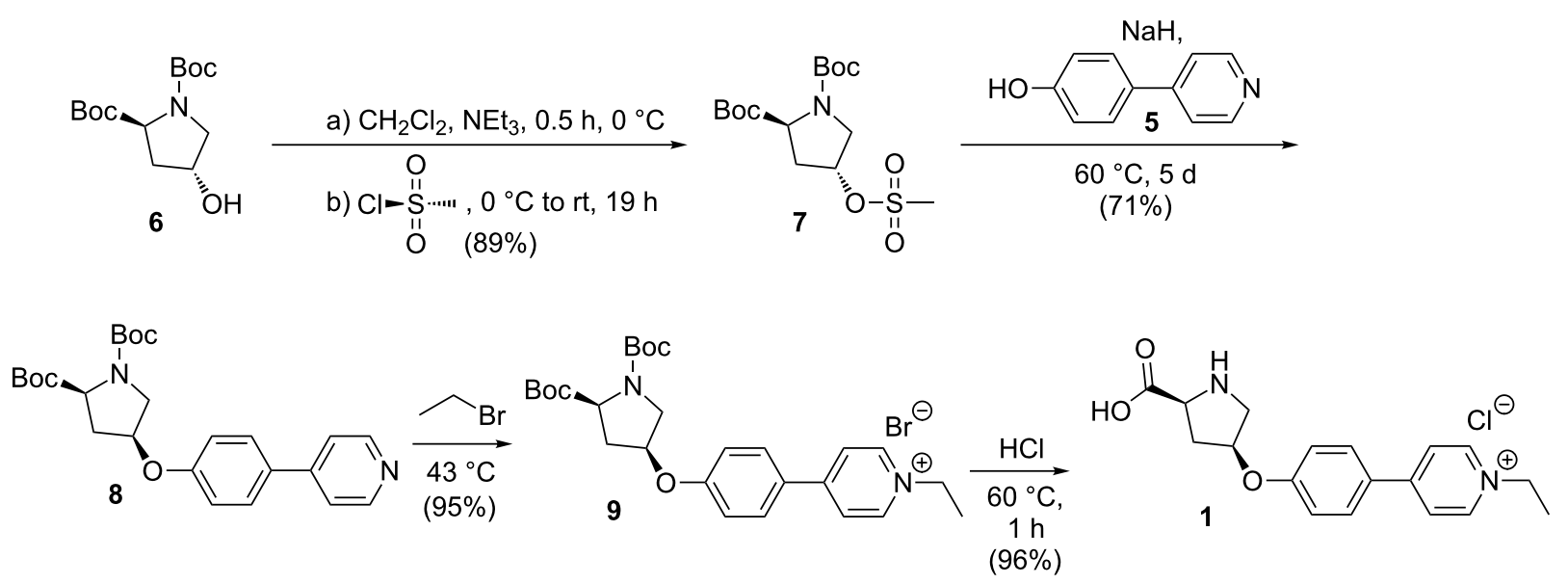


\section{Mechanism of the Jørgensen inversed aldol reaction}

According to the mechanistic model for enamine catalysis from List and Houk [36-38], the aldol reaction from Jørgensen should proceed via the catalytic cycle shown in Scheme 4. We began our experiments with a test whether the charge tag does not disturb the catalysis. Indeed, $\mathbf{1}$ can achieve the formation of aldol products $\mathbf{2} \mathbf{a}$ and $\mathbf{2 b}$, respectively, under the reaction conditions given in the literature [54]. Performed in simultaneous parallel reaction batches, $\mathbf{1}$ provides just about the same yields as unmodified proline and byproducts were not observed. Further, it is important to note that the substrates do not show any reaction when no catalyst, be it charge-tagged or not, is present in the solution.
The easiest way of ESI reaction monitoring - mixing the reagents and measuring ESI spectra after various time intervals - is restricted to reaction times longer than approximately one minute and therefore not appropriate for fast conversions like aldol reactions. We thus decided to use a more complicated experimental setup of two mixing tees connected on-line to the mass spectrometer (Figure 3) to detect individual intermediates of both reactions by ESIMS. These so-called continuous-flow experiments $[5,20]$ allow the sampling of reaction times down to seconds. Solutions of the reagents are mixed in the first microreactor and diluted to concentrations suitable for ESIMS in the second microreactor. The reaction time between the mixing event and the electrospray is determined by the flow rates and capillary lengths. Mass spectra of a solution of diethyl

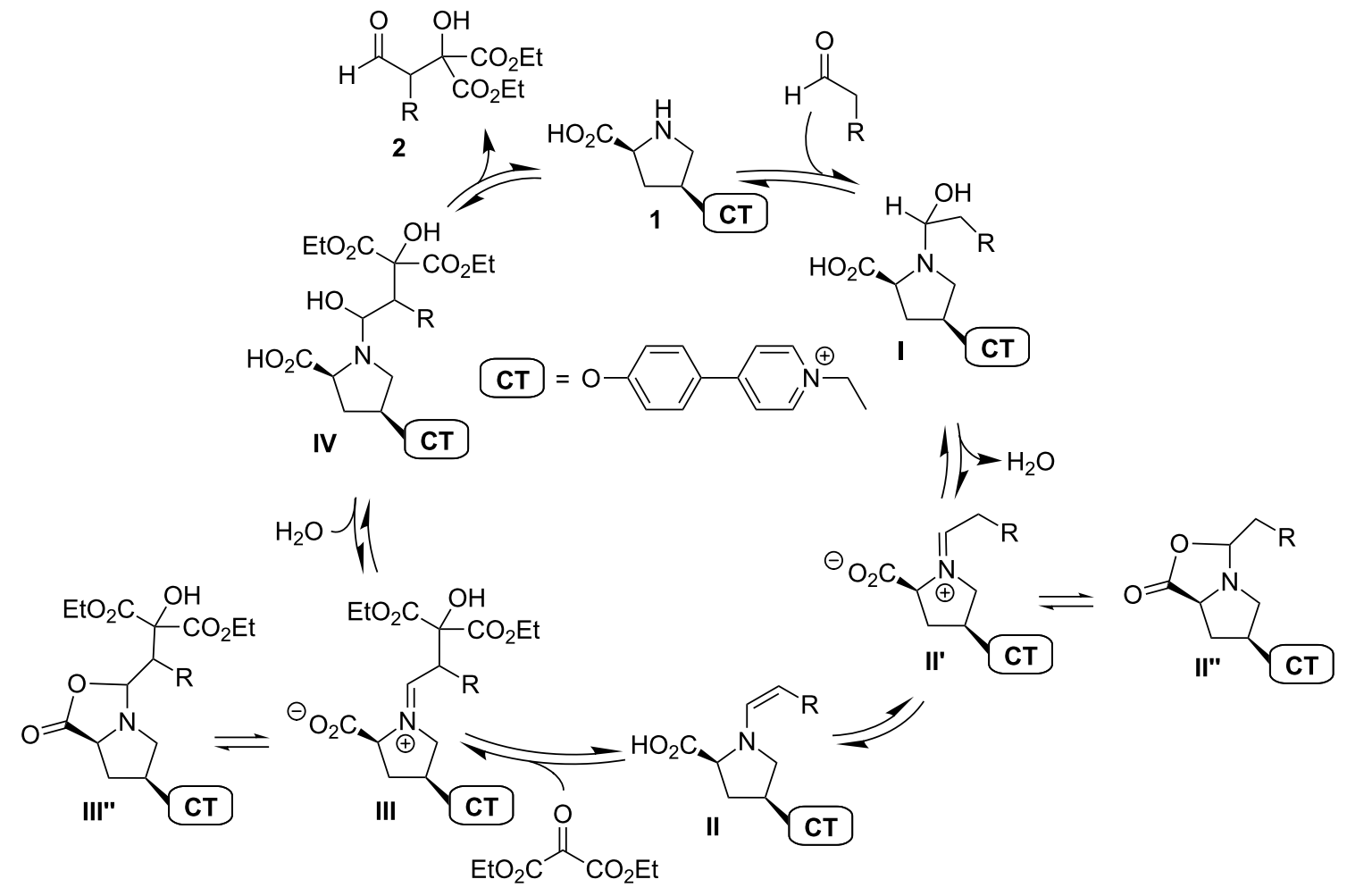

Scheme 4: Proposed catalytic cycle [36-38] for the aldol reaction with aldehyde donors [54]; CT = charge tag, $\mathbf{a}: \mathrm{R}=\mathrm{Ph}, \mathbf{b}: \mathrm{R}=\mathrm{Et}$.

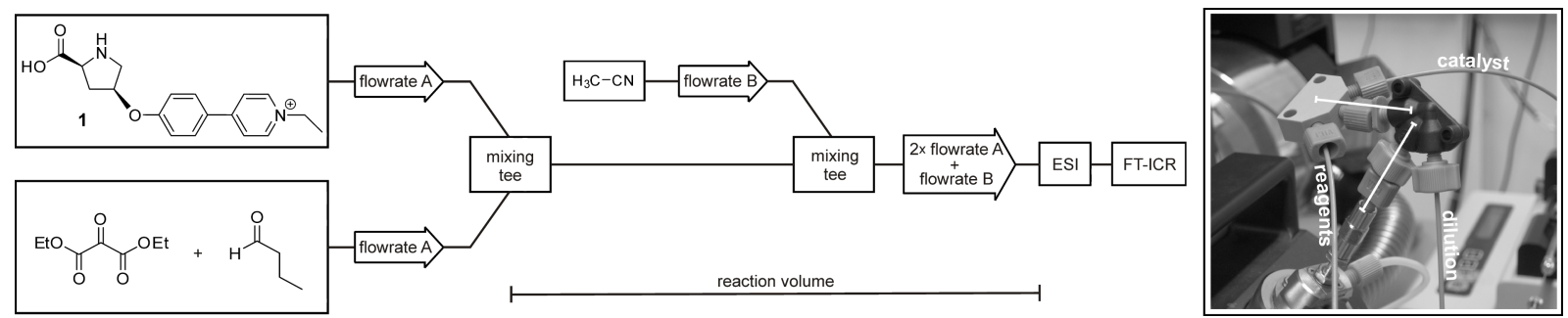

Figure 3: Experimental setup for continuous-flow ESIMS experiments using two mixing tee microreactors directly coupled to the ESI needle. 
ketomalonate, butyraldehyde and unmodified L-proline or $\mathbf{1}$, respectively, are depicted in Figure 4.

The mass spectra shown in Figure 4 do not exhibit abundant signals for the reactants, even though these are present in the solution in excess to all other species, a fact that is due to the poor ESI response of ketoesters and even more so of aldehydes. In the case of the proline-catalyzed solution (Figure 4a), the catalyst is not visible either, because of an instrumental discrimination of low masses unfortunately unavoidable with our instrument. Instead, two expected intermediates of the catalytic cycle indeed are observed in reasonable abundances (Figure 4a): The signal at $\mathrm{m} / \mathrm{z} 170.12$ corresponds to [ $\mathbf{I} \mathbf{b}_{\text {untagged }}$ $+\mathrm{H}]^{+}$and the one at $m / z 344.17$ is assigned to [ $\mathbf{I I I b}_{\text {untagged }}+$ $\mathrm{H}]^{+}$. In contrast, signals for the remaining two intermediates $\mathbf{I} \mathbf{b}_{\text {untagged }}$ and $\mathbf{I V \mathbf { b } _ { \text { untagged } }}$ have not been found, which probably is due to their very low concentration in the reaction equilibria as well as to their facile fragmentation during ESI. Note that the group of Metzger has successfully achieved the detec- tion of a similar intermediate for the aldol reaction beween acetone and selected benzaldehydes using rather unusual and presumably extremely soft ESI conditions, and their results indeed confirm its facile fragmentation [20].

Interestingly, the signal at $\mathrm{m} / \mathrm{z} 290.12$ can be assigned to a further transient species of the reaction - it corresponds to a protonated adduct of proline with diethyl ketomalonate. This adduct might simply be a non-covalently bound aggregate, i.e., a typical ESI phenomenon [2], but with regard to the rather low concentrations used here and the observation of the analogous species in the proton-free charge-tagged case (see below), we prefer its assignment to a hemiaminal species formed in analogy to intermediate $\mathbf{I}$ by interaction of the proline nitrogen with the keto group of the ketomalonate (structure depicted in Figure $4 \mathrm{a}$ ). In this special case, elimination of water is not possible due to the lack of adjacent hydrogen atoms. Its formation thus represents an off-cycle equilibrium dead-end in the course of the intended inverse aldol reaction.

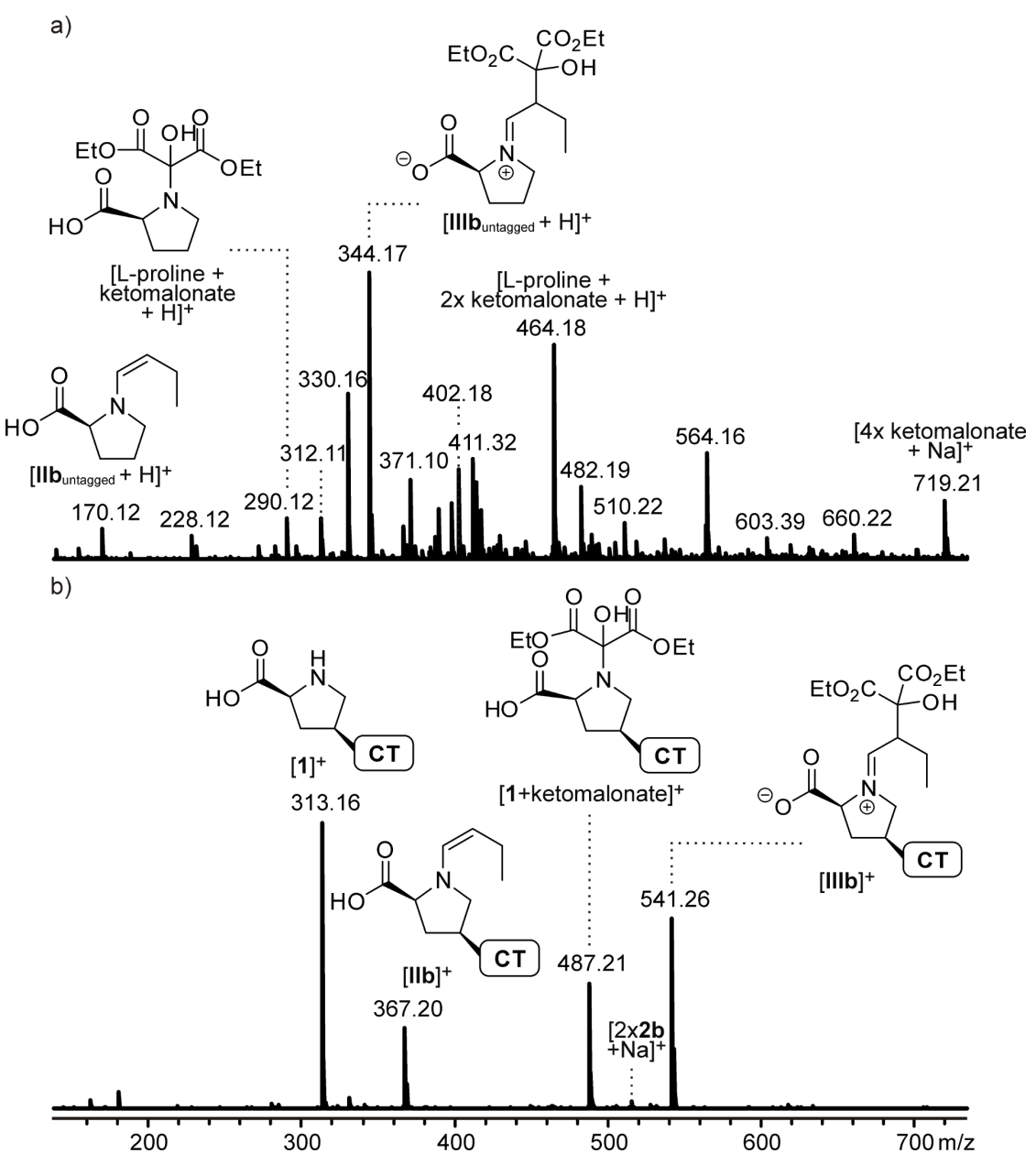

Figure 4: ESI mass spectra of acetonitrile solutions of diethyl ketomalonate and butyraldehyde (a) with unmodified L-proline or (b) with the chargetagged catalyst 1 recorded with the continous-flow setup shown in Figure 3. 
In light of the relatively high abundances observed for the reaction intermediates catalyzed by uncharged L-proline, the implementation of a charge tag might have been considered unneccessary. However, the effect of using the charge-tagged catalyst 1 is impressive (Figure 4b). The obvious reduction of spectral complexity and chemical noise due to the strongly enhanced ESI response of 1 and all its derivatives underlines the great benefits of the charge-tagging strategy. In addition to the catalyst 1 at $\mathrm{m} / \mathrm{z}$ 313.16, the three transient species discussed above are found almost exclusively and in very high abundances, i.e., the enamine $[\mathbf{I I b}]^{+}$at $\mathrm{m} / \mathrm{z} 367.20$, the iminium [IIIb] $]^{+}$at $\mathrm{m} / \mathrm{z}$ 541.26 and the side product $[1+\text { ketomalonate }]^{+}$at $m / z 487.21$. Please note that the abundance of the latter varies significantly between different reaction runs, in contrast to the signals of the other intermediates whose appearances are highly reproducible. Very similar findings are observed when phenylacetaldehyde instead of butyraldehyde is used. In particular, intermediates $[\mathbf{I I a}]^{+}$and $[\mathbf{I I I a}]^{+}$have been detected in high abundances.
Again, we unfortunately have not been successful in finding suitable electrospray conditions to detect the fragile intermediates $[\mathbf{I a}]^{+} /[\mathbf{I} \mathbf{b}]^{+}$and $[\mathbf{I V a}]^{+} /[\mathbf{I V b}]^{+}$. More importantly, however, additional species that are not present in the unlabeled reference system have not been observed. There are no indications for an interference of the charge tag with the catalysis, in contrast to the findings with the flexible imidazolium-labeled proline derivatives reported previously [43].

The mere detection of ions at $m / z 415.20(\mathrm{R}=\mathrm{Ph})$ and 367.20 $(\mathrm{R}=\mathrm{Et})$, respectively, is not a proof for the presence of reactive enamines $[\mathbf{I I a}]^{+} /[\mathbf{I I} \mathbf{b}]^{+}$since the isomeric zwitterionic iminiums $[\mathbf{I I} ' \mathbf{a}]^{+} /[\mathbf{I I} ' \mathbf{b}]^{+}$and oxazolidinones $\left[\mathbf{I I} \mathbf{I}^{\prime} \mathbf{a}\right]^{+} /\left[\mathbf{I I} \mathbf{I}^{\prime} \mathbf{b}\right]^{+}$ (Scheme 4) have the same elemental composition. Using one of the most important mass spectrometric means for structure elucidation, collision-induced dissociation (CID) experiments have been perfomed. The results for $\mathrm{R}=\mathrm{Et}$ are shown in Figure 5 .

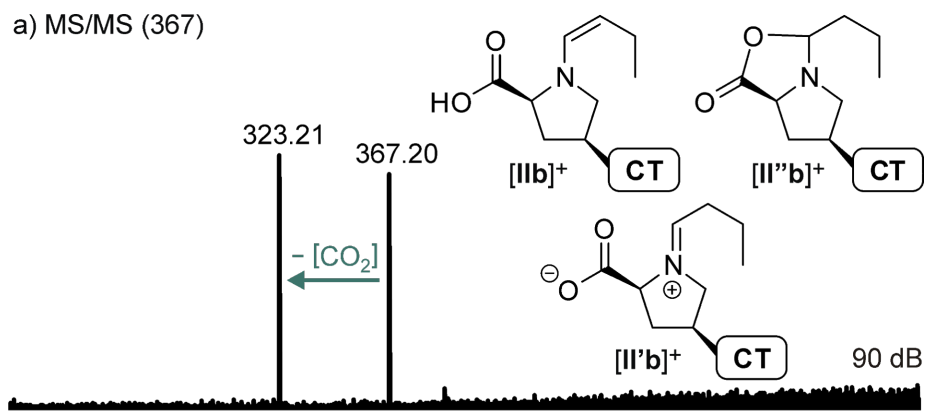

b) $M S / M S(423)$

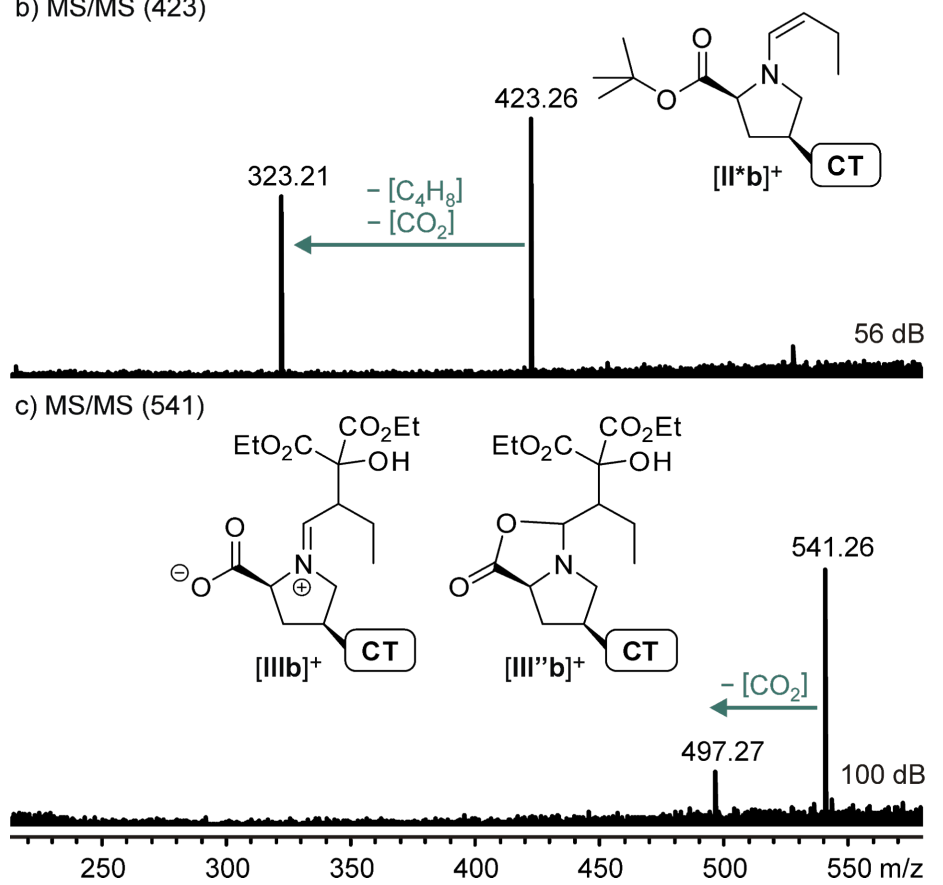

Figure 5: ESI(+) CID MS/MS spectra of mass-selected intermediates a) [IIb] $\left.]^{+}, \mathrm{b}\right)$ the butyl ester derivative $\left.\left[\mathrm{II}{ }^{*} \mathbf{b}\right]^{+}, \mathrm{c}\right)[\mathrm{IIIb}]^{+}$ 
All four mass-selected ions $[\mathbf{I I a}]^{+} /[\mathbf{I I} \mathbf{b}]^{+}$and $[\mathbf{I I I a}]^{+} /[\mathbf{I I I} \mathbf{I b}]^{+}$ show a very strong propensity to expel $\mathrm{CO}_{2}$ which even happens during the ESI process via in-source fragmentation when slightly harsher ionization conditions are used. This fragmentation is in perfect accordance with the zwitterionic iminium structures II' and III and can also be rationalized for the oxazolidinone alternative II', whereas it requires an additional hydrogen shift from the enamine structure II. On the other hand, the comparison with the fragmentation of the structurally related ion $[\mathbf{I I} * \mathbf{b}]^{+}$(Figure $5 b$ ) is instructive. It doubtlessly possesses an enamine structure since it can neither form a zwitterionic iminium ion nor undergo lactonization to oxazolidinone II''b because of its tert-butyl blocked carboxylic acid function. The fragmentation of $[\mathbf{I I} * \mathbf{b}]^{+}$exclusively consists of a loss of $\left[\mathrm{C}_{5}, \mathrm{H}_{8}, \mathrm{O}_{2}\right]$ which should correspond to a concerted or very fast stepwise elimination of isobutene and $\mathrm{CO}_{2}$ leading to the same product ion at $\mathrm{m} / \mathrm{z} 323.21$ as the expulsion of $\mathrm{CO}_{2}$ from $\mathrm{m} / \mathrm{z}$ 367.20. Interpreting the isobutene loss as a closedshell McLafferty-type rearrangement leads to the postulation of a (very short-lived undetected) intermediate enamine $[\mathbf{I I I b}]^{+}$ which then obviously is able to undergo a facile $\mathrm{CO}_{2}$ elimination. Thus, the fragmentation spectra unfortunately do not allow a clear discrimination of the three possible structures II, II', and II'.

Marquez and Metzger mass-selected a signal corresponding to the protonated enamine from acetone and untagged L-proline and observed the elimination of $\mathrm{CH}_{2} \mathrm{O}_{2}$ (formic acid) instead of $\mathrm{CO}_{2}$ as main fragmentation component during CID [20]. The protonation during the ESI process presumably occurs at the nitrogen atom which enables a direct 1,2-elimination of formic acid. In our case, the respective charge-tagged species are detected in their original form without additional proton which explains the differing fragmentation route.

To monitor the temporal evolution of intermediates during the aldol reaction with the continous-flow setup, series of ESI spectra at different reaction time stages have been recorded by varying the flow rate of the analyte solutions or by changing the length of the capillary connecting both mixing tees. A resulting graph of the normalized relative intensities vs calculated reaction time is provided in Figure 6.

The graph displays a rise of the concentration of IIb during the first seconds of the reaction accompanied by a decrease of $\mathbf{1}$. Subsequently, an increase of IIIb occurs indicating that IIIb is formed out of IIb which is consistent with the mechanism in Scheme 4. The gradual increase of the final aldol product $\mathbf{2 b}$ is visible as well; an enlargement of a factor of 100 has been used in the presentation of Figure 6 due to its much lower ESI response. Overall, these experiments reflect a very reasonable

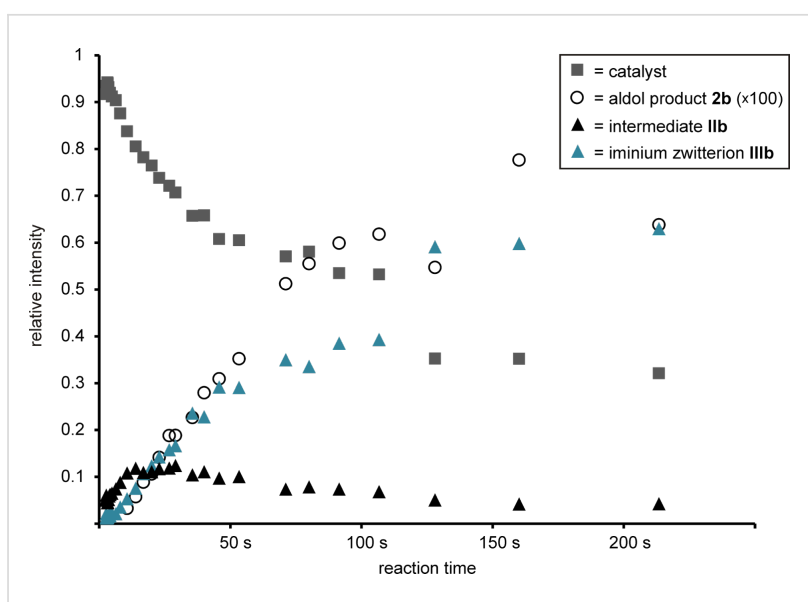

Figure 6: Normalized relative intensities in ESI spectra recorded for the inverse aldol reaction of butyraldehyde, diethyl ketomalonate and charge-tagged catalyst 1 at different time stages using the continousflow setup with two microreactors shown in Figure 3.

qualitative picture of the reaction behaviour and show that the use of catalyst $\mathbf{1}$ is suitable for the examination of L-prolinecatalyzed reactions via ESIMS. However, we refrain from a quantitative kinetic modeling of the data to extract rate constants [8] because we encountered certain limitations of the method. Most importantly, we could not obtain an exact reproducibility of reaction times, probably because of quasi-unavoidable variations in the actual (dead) volumes of the setup inter alia due to varying minor capillary blockings. Moreover, we face a slight increase of signal abundances with measuring time (not reaction time) because analytes gradually accumulate in the system the longer their solutions are passed through. The extent of this effect depends on the height of the flow rate which necessarily has to be changed when observing a reaction process with the continuous-flow method. Nevertheless, we would like to emphasize that the quality of the experiments surely suffices to depict the "chronological trend" of the reaction process.

\section{Conclusion}

We present the synthesis of the charge-tagged L-proline derived catalyst $\mathbf{1}$ in which a rigid phenylpyridine linker fixes the charge tag far away from the catalytically active center in order to avoid unwanted interactions. In a comparative continousflow electrospray mass spectrometric study, the new charged catalyst $\mathbf{1}$ and neutral L-proline have been used to investigate the proline-catalyzed inverse crossed aldol reaction of aldehydes with diethyl ketomalonate. Two key intermediates of the List-Houk mechanism for enamine catalysis in addition to a transient off-cycle species could be observed experimentally. The use of $\mathbf{1}$ further allows facile access to a qualitative picture of the temporal evolution of catalyst-containing intermediates. We plan to use the new proline catalyst with a non-interfering charge-label presented here as a tool to study the templating 
role of the hydroxy group in L-proline-catalyzed reactions in the gas-phase in the near future.

\section{Experimental Synthesis}

Reactions under inert gas atmosphere were performed under argon using standard Schlenk techniques and oven-dried glassware prior to use. Thin-layer chromatography was performed on aluminum TLC plates silica gel $60 \mathrm{~F}_{254}$ from Merck. Detection was carried out under UV light (254 and $366 \mathrm{~nm}$ ). Products were purified by column chromatography on silica gel 60 (40-63 $\mu \mathrm{m})$ from Merck. The ${ }^{1} \mathrm{H}$ and ${ }^{13} \mathrm{C}$ NMR spectra were recorded on a Bruker Avance 300 spectrometer, at 300.1 and 75.5 MHz, or a Bruker AM 400, at 400.1 MHz and $100.6 \mathrm{MHz}$, at $293 \mathrm{~K}$, respectively. The ${ }^{1} \mathrm{H}$ NMR chemical shifts are reported on the $\delta$ scale (ppm) relative to residual non-deuterated solvent as the internal standard. The ${ }^{13} \mathrm{C}$ NMR chemical shifts are reported on the $\delta$ scale (ppm) relative to deuterated solvent as the internal standard. Signals were assigned on the basis of ${ }^{1} \mathrm{H},{ }^{13} \mathrm{C}$, HMQC, and HMBC NMR experiments. Most solvents were dried, distilled, and stored under argon according to standard procedures. 4-Bromophenol, 4-pyridinylboronic acid, trans- $N$-(tert-butoxycarbonyl)-4-hydroxy-L-proline, L-proline, diethyl ketomalonate, phenylacetaldehyde and butyraldehyde were used as received from commercial sources.

4-Bromophenol methoxymethyl ether (3) [56]: 4-Bromophenol (3.00 g, $17.2 \mathrm{mmol})$ was dried under reduced pressure and dissolved in dry THF $(160 \mathrm{~mL})$ under inert gas atmosphere. $\mathrm{NaH}(1.32 \mathrm{~g}, 52.0 \mathrm{mmol})$ was added and the mixture was stirred at $\mathrm{rt}$ for $0.5 \mathrm{~h}$. Methoxymethyl chloride $(2.08 \mathrm{~mL}, 26.0 \mathrm{mmol})$ was added dropwise and the resulting suspension was stirred for $19 \mathrm{~h}$. The reaction was quenched by the addition of a $\mathrm{MeOH} /$ $\mathrm{H}_{2} \mathrm{O}$ mixture $(1: 1,150 \mathrm{~mL})$ and the aqueous phase was extracted with $\mathrm{CH}_{2} \mathrm{Cl}_{2}(4 \times 50 \mathrm{~mL})$. The combined organic extracts were dried with $\mathrm{MgSO}_{4}$ and the solvents were removed in vacuo. The crude product was purified by column chromatography on silica gel using cyclohexane/ethyl acetate (10:1) as eluent $\left(R_{\mathrm{f}} 0.61\right)$. Compound $\mathbf{3}$ was obtained as colorless oil (3.38 g, 90\%). The spectroscopic data confirm the reported ones [56].

4-[4-(Methoxymethoxy)phenyl]pyridine (4) [55]: 4-Bromophenol methoxymethyl ether (3, $1.5 \mathrm{~g}, 6.9 \mathrm{mmol})$, 4-pyridinylboronic acid (1.02 g, $7.5 \mathrm{mmol})$, [1,1'-bis(diphenylphosphino)ferrocene]palladium(II) dichloride dichloromethane complex (0.22 g, $0.28 \mathrm{mmol})$ and $\mathrm{Na}_{2} \mathrm{CO}_{3}(8.78 \mathrm{~g}, 82.4 \mathrm{mmol})$ were suspended in a $\mathrm{H}_{2} \mathrm{O} / 1,2$-dimethoxyethane mixture (1:3, $75 \mathrm{~mL}$ ), heated to $100{ }^{\circ} \mathrm{C}$ und stirred for $16 \mathrm{~h}$. The resulting mixture was filtered and the filtrate was mixed with $\mathrm{H}_{2} \mathrm{O}$ $(75 \mathrm{~mL})$ and $\mathrm{CH}_{2} \mathrm{Cl}_{2}(75 \mathrm{~mL})$ for phase separation. The aqueous phase was extracted with $\mathrm{CH}_{2} \mathrm{Cl}_{2}(2 \times 75 \mathrm{~mL})$, the combined organic extracts were dried with $\mathrm{MgSO}_{4}$ and the solvents were removed in vacuo. The crude product was purified by column chromatography on silica gel using ethyl acetate with $5 \%$ triethylamine as eluent $\left(R_{\mathrm{f}} 0.50\right)$. Compound 4 was obtained as white solid (1.31 g, 88\%). The spectroscopic data confirm the reported ones [55].

4-(Pyridine-4'-yl)phenol (5) [55] and (2S,4R)-tert-butyl $N$-tert-butyloxycarbonyl-4-hydroxyprolinate (6) [57] were prepared according to literature protocols.

(2S,4R)-tert-Butyl $N$-tert-butoxycarbonyl-4-oxymethanesulfonyloxyprolinate (7) was prepared according to a known procedure [58] which was slightly modified: $(2 S, 4 R)$-tert-butyl $N$-tert-butyloxycarbonyl-4-hydroxyprolinate $(6,3.14 \mathrm{~g}$, $10.9 \mathrm{mmol})$ was dissolved in $\mathrm{CH}_{2} \mathrm{Cl}_{2}(55 \mathrm{~mL})$ and cooled to $0{ }^{\circ} \mathrm{C}$. Triethylamine $(3.01 \mathrm{~mL}, 21.5 \mathrm{mmol})$ was added and the mixture was stirred for $0.5 \mathrm{~h}$. Methanesulfonyl chloride $(1.33 \mathrm{~mL}, 17.1 \mathrm{mmol})$ was added dropwise over $10 \mathrm{~min}$ and the resulting solution was stirred overnight without further cooling. The reaction was quenched by the addition of a saturated solution of $\mathrm{NaHCO}_{3}(70 \mathrm{~mL})$ and the aqueous phase was extracted with $\mathrm{CH}_{2} \mathrm{Cl}_{2}(2 \times 50 \mathrm{~mL})$. The combined organic extracts were dried with $\mathrm{MgSO}_{4}$ and the solvents were removed in vacuo. The crude product was purified by column chromatography on silica gel using cyclohexane/ethyl acetate $(2: 3)$ as eluent $\left(R_{\mathrm{f}} 0.61\right)$. Compound 7 was obtained as colorless solid (3.55 g, 89\%). Crystals suitable for X-ray analysis have been obtained by slow diffusion of cyclohexane into a $\mathrm{Et}_{2} \mathrm{O}$ solution of 7. ${ }^{1} \mathrm{H} \mathrm{NMR}$ (400 MHz, CD $\left.\mathrm{CD}_{3} \mathrm{OD}\right) \delta 5.26\left(\mathrm{~s}, 1 \mathrm{H}, \mathrm{CH}_{2} \mathrm{CHCH}_{2}\right), 4.30-4.23$ (m, $\left.1 \mathrm{H}, \mathrm{CH}_{2} \mathrm{CHN}\right), 3.83-3.76\left(\mathrm{~m}, 1 \mathrm{H}, \mathrm{NCH}_{2} \mathrm{CH}\right), 3.70-3.63(\mathrm{~m}$, $\left.1 \mathrm{H}, \mathrm{NCH}_{2} \mathrm{CH}\right), 3.14\left(\mathrm{~s}, 3 \mathrm{H}, \mathrm{S}-\mathrm{CH}_{3}\right), 2.67-2.56(\mathrm{~m}, 1 \mathrm{H}$, $\left.\mathrm{CHCH}_{2} \mathrm{CH}\right), 2.28-2.19\left(\mathrm{~m}, 1 \mathrm{H}, \mathrm{CHCH}_{2} \mathrm{CH}\right), 1.50-1.44(\mathrm{~m}$, $\left.18 \mathrm{H}, \mathrm{C}\left(\mathrm{CH}_{3}\right)_{3}\right) \mathrm{ppm} ;{ }^{1} \mathrm{H} \mathrm{NMR}\left(400 \mathrm{MHz}, \mathrm{CD}_{3} \mathrm{OD}, 333 \mathrm{~K}\right) \delta$ $5.26\left(\mathrm{~s}, 1 \mathrm{H}, \mathrm{CH}_{2} \mathrm{CHCH}_{2}\right), 4.30-4.26\left(\mathrm{~m}, 1 \mathrm{H}, \mathrm{CH}_{2} \mathrm{CHN}\right)$, 3.83-3.74 (m, 1H, $\left.\mathrm{NCH}_{2} \mathrm{CH}\right), 3.72-3.63\left(\mathrm{~m}, 1 \mathrm{H}, \mathrm{NCH}_{2} \mathrm{CH}\right)$, $3.12\left(\mathrm{~s}, 3 \mathrm{H}, \mathrm{S}-\mathrm{CH}_{3}\right), 2.67-2.54\left(\mathrm{~m}, 1 \mathrm{H}, \mathrm{CHCH}_{2} \mathrm{CH}\right), 2.30-2.20$ $\left(\mathrm{m}, 1 \mathrm{H}, \mathrm{CHCH}_{2} \mathrm{CH}\right), 1.48\left(\mathrm{~s}, 9 \mathrm{H}, \mathrm{C}\left(\mathrm{CH}_{3}\right)_{3}\right), 1.46(\mathrm{~s}, 9 \mathrm{H}$, $\left.\mathrm{C}\left(\mathrm{CH}_{3}\right)_{3}\right) \mathrm{ppm} ;{ }^{13} \mathrm{C} \mathrm{NMR}\left(100 \mathrm{MHz}, \mathrm{CD}_{3} \mathrm{OD}\right) \delta 173.0 / 172.9$ $(C=\mathrm{O}), 155.6(C=\mathrm{O}), 83.1\left(C\left(\mathrm{CH}_{3}\right)_{3}\right), 82.1 / 81.9\left(C\left(\mathrm{CH}_{3}\right)_{3}\right)$, 80.6/79.9 $\left(\mathrm{CH}_{2} \mathrm{CHCH}_{2}\right), 59.5 / 59.4\left(\mathrm{CH}_{2} \mathrm{CHN}\right), 54.1 / 53.7$ $\left(\mathrm{NCH}_{2} \mathrm{CH}\right), 38.3\left(\mathrm{~S}-\mathrm{CH}_{3}\right), 37.3\left(\mathrm{CHCH}_{2} \mathrm{CH}\right), 28.6\left(\mathrm{C}\left(\mathrm{CH}_{3}\right)_{3}\right)$, 28.3/28.2 $\left(\mathrm{C}\left(\mathrm{CH}_{3}\right)_{3}\right) \mathrm{ppm} ;{ }^{13} \mathrm{C} \mathrm{NMR}\left(125 \mathrm{MHz}, \mathrm{CD}_{3} \mathrm{OD}, 333\right.$ K) $\delta 172.9(C=\mathrm{O}), 155.6(C=\mathrm{O}), 83.1\left(C\left(\mathrm{CH}_{3}\right)_{3}\right), 82.1$ $\left(\mathrm{C}\left(\mathrm{CH}_{3}\right)_{3}\right), 80.5 / 79.8\left(\mathrm{CH}_{2} \mathrm{CHCH}_{2}\right), 59.5\left(\mathrm{CH}_{2} \mathrm{CHN}\right), 53.9 / 53.5$ $\left(\mathrm{NCH}_{2} \mathrm{CH}\right), 38.5\left(\mathrm{~S}-\mathrm{CH}_{3}\right), 38.3 / 37.3\left(\mathrm{CHCH}_{2} \mathrm{CH}\right), 28.7$ $\left(\mathrm{C}\left(\mathrm{CH}_{3}\right)_{3}\right), 28.3\left(\mathrm{C}\left(\mathrm{CH}_{3}\right)_{3}\right)$ ppm; HRESIMS $(\mathrm{m} / \mathrm{z}):[\mathrm{M}+\mathrm{Na}]^{+}$ calcd for $\mathrm{C}_{15} \mathrm{H}_{27} \mathrm{NNaO}_{7} \mathrm{~S}, 388.1406$; found, 388.1398. The NMR data are consistent with the reported ones measured in $\mathrm{CDCl}_{3}[58,60]$. 
(2S,4S)-tert-Butyl $N$-tert-butoxycarbonyl-4-(4-(pyridine-4yl)phenoxy)prolinate (8): 4-(Pyridine-4'-yl)phenol (5, $0.63 \mathrm{~g}$, $3.7 \mathrm{mmol})$ and $\mathrm{NaH}(0.14 \mathrm{~g}, 5.5 \mathrm{mmol})$ were dissolved in dry DMSO $(100 \mathrm{~mL})$ under inert gas atmosphere. The suspension was heated to $60{ }^{\circ} \mathrm{C}$ and stirred for $1.5 \mathrm{~h}$. $(2 S, 4 R)$-tert-Butyl $\mathrm{N}$-tert-butoxycarbonyl-4-methanesulfonyloxyprolinate (7, $1.33 \mathrm{~g}, 3.7 \mathrm{mmol}$ ) was added and the mixture was stirred for $5 \mathrm{~d}$ at $60{ }^{\circ} \mathrm{C}$. The reaction progress was controlled by thin-layer chromatography. The reaction was quenched by the addition of $\mathrm{H}_{2} \mathrm{O}(100 \mathrm{~mL})$ and the aqueous phase was extracted with $\mathrm{CH}_{2} \mathrm{Cl}_{2}(2 \times 80 \mathrm{~mL})$ and with $\mathrm{Et}_{2} \mathrm{O}(2 \times 80 \mathrm{~mL})$. The combined organic extracts were dried with $\mathrm{Na}_{2} \mathrm{SO}_{4}$ and the solvents were removed in vacuo. Remaining DMSO was removed by distillation. The crude product was purified by column chromatography on silica gel using cyclohexane/ethyl acetate (1:3) with $5 \%$ triethylamine as eluent $\left(R_{\mathrm{f}} 0.50\right)$. Compound $\mathbf{8}$ was obtained as colorless solid (1.14 g, 71\%). ${ }^{1} \mathrm{H}$ NMR (300 MHz, CD 3 OD) $\delta$ 8.55-8.45 (m, 2H, $\left.H_{\mathrm{o}-\mathrm{py}}\right), 7.72$ (d, $\left.{ }^{3} J=8.8 \mathrm{~Hz}, 2 \mathrm{H}, H_{\mathrm{m}-\mathrm{ph}}\right), 7.67$ $\left(\mathrm{d},{ }^{3} J=6.1 \mathrm{~Hz}, 2 \mathrm{H}, H_{\mathrm{m}-\mathrm{py}}\right), 7.06 / 7.00\left(\mathrm{~d},{ }^{3} J=8.8 \mathrm{~Hz}, 2 \mathrm{H}\right.$, $\left.H_{\mathrm{o}-\mathrm{ph}}\right), 5.06\left(\mathrm{~s}, 1 \mathrm{H}, \mathrm{CH}_{2} \mathrm{CHCH}_{2}\right), 4.41-4.26(\mathrm{~m}, 1 \mathrm{H}$, $\left.\mathrm{CH}_{2} \mathrm{CHN}\right), 3.86-3.72\left(\mathrm{~m}, 1 \mathrm{H}, \mathrm{NCH}_{2} \mathrm{CH}\right), 3.72-3.57(\mathrm{~m}, 1 \mathrm{H}$, $\left.\mathrm{NCH}_{2} \mathrm{CH}\right), 2.67-2.49\left(\mathrm{~m}, 1 \mathrm{H}, \mathrm{CHCH}_{2} \mathrm{CH}\right), 2.47-2.37(\mathrm{~m}, 1 \mathrm{H}$, $\left.\mathrm{CHCH}_{2} \mathrm{CH}\right), 1.51-1.40\left(\mathrm{~m}, 18 \mathrm{H}, \mathrm{C}\left(\mathrm{CH}_{3}\right)_{3}\right) \mathrm{ppm} ;{ }^{13} \mathrm{C} \mathrm{NMR}(75$ $\left.\mathrm{MHz}, \mathrm{CD}_{3} \mathrm{OD}\right) \delta 172.5 / 172.5(C=\mathrm{O}), 159.7 / 159.5(C=\mathrm{O})$, $156.0\left(C_{\mathrm{ph}}-\mathrm{O}\right), 150.4\left(C_{\mathrm{o}-\mathrm{py}}-\mathrm{H}\right), 150.1\left(C_{\mathrm{p}-\mathrm{py}}-\mathrm{C}\right), 131.7 / 131.4$ $\left(C_{\mathrm{p}-\mathrm{ph}}-\mathrm{C}\right), 129.6 / 129.4\left(C_{\mathrm{m}-\mathrm{ph}}-\mathrm{H}\right), 122.5\left(C_{\mathrm{m}-\mathrm{py}}-\mathrm{H}\right), 117.3 /$ 117.2/117.2 $\left(C_{\mathrm{o}-\mathrm{ph}}-\mathrm{H}\right), 82.9 / 82.7 / 82.6\left(\mathrm{C}_{\left.\left(\mathrm{CH}_{3}\right)_{3}\right), 81.9 / 81.6}\right.$ $\left(\mathrm{C}\left(\mathrm{CH}_{3}\right)_{3}\right), 77.2 / 76.2\left(\mathrm{CH}_{2} \mathrm{CHCH}_{2}\right), 60.1 / 59.8\left(\mathrm{CH}_{2} \mathrm{CHN}\right)$, 53.6/53.2 $\left(\mathrm{NCH}_{2} \mathrm{CH}\right), 37.1 / 36.4\left(\mathrm{CHCH}_{2} \mathrm{CH}\right), 28.7 / 28.6$ $\left(\mathrm{C}\left(\mathrm{CH}_{3}\right)_{3}\right), 28.4\left(\mathrm{C}\left(\mathrm{CH}_{3}\right)_{3}\right)$ ppm; HRESIMS $(\mathrm{m} / \mathrm{z}):[\mathrm{M}+\mathrm{H}]^{+}$ calcd for $\mathrm{C}_{25} \mathrm{H}_{33} \mathrm{~N}_{2} \mathrm{O}_{5}$, 441.2389; found, 441.2390.

4-(4-((3S,5S)-1,5-Bis(tert-butoxycarbonyl)pyrrolidine-3yloxy)phenyl)-1-ethylpyridinium bromide (9): $(2 S, 4 S)$-tertButyl N-tert-butoxycarbonyl-4-(4-(pyridine-4-yl)phenoxy)prolinate $(8,0.22 \mathrm{~g}, 0.5 \mathrm{mmol})$ was dissolved in bromoethane (13.0 mL, $174.2 \mathrm{mmol}$ ), heated to $43{ }^{\circ} \mathrm{C}$ and stirred for $5 \mathrm{~d}$. Bromoethane was removed in vacuo. Compound 9 was obtained as yellowish-brown solid (0.26 g, 95\%). ${ }^{1} \mathrm{H}$ NMR (400 $\left.\mathrm{MHz}, \mathrm{CD}_{3} \mathrm{OD}\right) \delta 8.89\left(\mathrm{~d},{ }^{3} J=6.8 \mathrm{~Hz}, 2 \mathrm{H}, H_{\mathrm{o}-\mathrm{py}}\right), 8.35\left(\mathrm{~d},{ }^{3} J=\right.$ $\left.6.8 \mathrm{~Hz}, 2 \mathrm{H}, H_{\mathrm{m}-\mathrm{py}}\right), 8.08 / 7.99\left(\mathrm{~m}, 2 \mathrm{H}, H_{\mathrm{m}-\mathrm{ph}}\right), 7.18 / 7.11\left(\mathrm{~d},{ }^{3} J=\right.$ $\left.8.9 \mathrm{~Hz}, 2 \mathrm{H}, H_{\mathrm{o}-\mathrm{ph}}\right), 5.19-5.13\left(\mathrm{~m}, 1 \mathrm{H}, \mathrm{CH}_{2} \mathrm{CHCH}_{2}\right), 4.63$ (q, ${ }^{3} \mathrm{~J}$ $\left.=7.4 \mathrm{~Hz}, 2 \mathrm{H}, \mathrm{CH}_{2} \mathrm{CH}_{3}\right), 4.43-4.36\left(\mathrm{~m}, 1 \mathrm{H}, \mathrm{CH}_{2} \mathrm{CHN}\right)$, 3.89-3.73 (m, $\left.1 \mathrm{H}, \mathrm{NCH}_{2} \mathrm{CH}\right), 3.71-3.58\left(\mathrm{~m}, 1 \mathrm{H}, \mathrm{NCH}_{2} \mathrm{CH}\right)$, 2.71-2.55 (m, $\left.1 \mathrm{H}, \mathrm{CHCH}_{2} \mathrm{CH}\right), 2.47-2.40\left(\mathrm{~m}, 1 \mathrm{H}, \mathrm{CHCH}_{2} \mathrm{CH}\right)$, $1.67\left(\mathrm{t},{ }^{3} \mathrm{~J}=7.4 \mathrm{~Hz}, 3 \mathrm{H}, \mathrm{CH}_{2} \mathrm{CH}_{3}\right), 1.52-1.42(\mathrm{~m}, 18 \mathrm{H}$, $\left.\mathrm{C}\left(\mathrm{CH}_{3}\right)_{3}\right) \mathrm{ppm} ;{ }^{13} \mathrm{C} \mathrm{NMR}\left(100 \mathrm{MHz}, \mathrm{CD}_{3} \mathrm{OD}\right) \delta 172.5 / 172.4$ $(C=\mathrm{O}), 162.0\left(C_{\mathrm{ph}}-\mathrm{O}\right), 157.0\left(C_{\mathrm{p}-\mathrm{py}}-\mathrm{C}\right), 155.9(C=\mathrm{O}), 145.2$ $\left(C_{\text {o-py }}-\mathrm{H}\right), 131.2 / 131.1\left(C_{\mathrm{m}-\mathrm{ph}}-\mathrm{H}\right), 127.5\left(C_{\mathrm{p}-\mathrm{ph}}-\mathrm{C}\right), 125.0$ $\left(C_{\mathrm{m}-\mathrm{py}}-\mathrm{H}\right), 117.8 / 117.7\left(C_{\mathrm{o}-\mathrm{ph}}-\mathrm{H}\right), 82.7 / 82.6\left(\mathrm{C}_{\left.\left(\mathrm{CH}_{3}\right)_{3}\right), 81.6}\right.$ $\left(\mathrm{C}\left(\mathrm{CH}_{3}\right)_{3}\right), 77.6 / 76.6\left(\mathrm{CH}_{2} \mathrm{CHCH}_{2}\right), 60.0 / 59.8\left(\mathrm{CH}_{2} \mathrm{CHN}\right), 57.2$
$\left(\mathrm{CH}_{2} \mathrm{CH}_{3}\right), 53.6 / 53.2\left(\mathrm{NCH}_{2} \mathrm{CH}\right), 37.1 / 36.3\left(\mathrm{CHCH}_{2} \mathrm{CH}\right), 28.7 /$ $28.6\left(\mathrm{C}\left(\mathrm{CH}_{3}\right)_{3}\right), 28.3\left(\mathrm{C}\left(\mathrm{CH}_{3}\right)_{3}\right), 16.7\left(\mathrm{CH}_{2} \mathrm{CH}_{3}\right)$ ppm; HRESIMS $(m / z)$ : $[\mathrm{M}]^{+}$calcd for $\mathrm{C}_{27} \mathrm{H}_{37} \mathrm{~N}_{2} \mathrm{O}_{5}, 469.2697$; found, 469.2692 .

4-(4-((3S,5S)-5-Carboxypyrrolidin-3-yloxy)phenyl)-1-ethylpyridinium bromide (1) was prepared analogous to a known procedure [59] and obtained as beige-brown solid (96\%). ${ }^{1} \mathrm{H}$ NMR (400 MHz, CD 3 OD) $\delta 8.92\left(\mathrm{~d},{ }^{3} J=6.4 \mathrm{~Hz}, 2 \mathrm{H}, \mathrm{H}_{\mathrm{o}-\mathrm{py}}\right)$, $8.37\left(\mathrm{~d},{ }^{3} \mathrm{~J}=6.4 \mathrm{~Hz}, 2 \mathrm{H}, \mathrm{H}_{\mathrm{m}-\mathrm{py}}\right), 8.06\left(\mathrm{~d},{ }^{3} \mathrm{~J}=8.6 \mathrm{~Hz}, 2 \mathrm{H}\right.$, $\left.\mathrm{H}_{\mathrm{m}-\mathrm{ph}}\right), 7.27 / 7.20\left(\mathrm{~d},{ }^{3} \mathrm{~J}=8.6 \mathrm{~Hz}, 2 \mathrm{H}, \mathrm{H}_{\mathrm{o}-\mathrm{ph}}\right), 5.42(\mathrm{~s}, 1 \mathrm{H}$, $\left.\mathrm{CH}_{2} \mathrm{CHCH}_{2}\right), 4.73-4.58\left(\mathrm{~m}, 3 \mathrm{H}, \mathrm{CH}_{2} \mathrm{CH}_{3}\right.$ and $\left.\mathrm{CH}_{2} \mathrm{CHN}\right)$, 3.82-3.62 (m, $\left.2 \mathrm{H}, \mathrm{NCH}_{2} \mathrm{CH}\right), 2.85-2.73\left(\mathrm{~m}, 1 \mathrm{H}, \mathrm{CHCH}_{2} \mathrm{CH}\right)$, $2.71-2.63\left(\mathrm{~m}, 1 \mathrm{H}, \mathrm{CHCH}_{2} \mathrm{CH}\right), 1.67\left(\mathrm{t},{ }^{3} \mathrm{~J}=7.3 \mathrm{~Hz}, 3 \mathrm{H}\right.$, $\left.\mathrm{CH}_{2} \mathrm{CH}_{3}\right) \mathrm{ppm} ;{ }^{13} \mathrm{C} \mathrm{NMR}\left(100 \mathrm{MHz}, \mathrm{CD}_{3} \mathrm{OD}\right) \delta 171.0(\mathrm{C}=\mathrm{O})$, $160.9\left(C_{\mathrm{ph}}-\mathrm{O}\right), 156.9\left(C_{\mathrm{p}-\mathrm{py}}-\mathrm{C}\right), 145.4\left(C_{\mathrm{o}-\mathrm{py}}-\mathrm{H}\right), 131.0$ $\left(C_{\mathrm{m}-\mathrm{ph}}-\mathrm{H}\right), 128.5\left(C_{\mathrm{p}-\mathrm{ph}}-\mathrm{C}\right), 125.2\left(C_{\mathrm{m}-\mathrm{py}}-\mathrm{H}\right), 118.0\left(C_{\mathrm{o}-\mathrm{ph}}-\mathrm{H}\right)$, 77.3/76.7 $\left(\mathrm{CH}_{2} \mathrm{CHCH}_{2}\right), 59.8\left(\mathrm{CH}_{2} \mathrm{CHN}\right), 57.4\left(\mathrm{CH}_{2} \mathrm{CH}_{3}\right), 52.7$ $\left(\mathrm{NCH}_{2} \mathrm{CH}\right), 35.7\left(\mathrm{CHCH}_{2} \mathrm{CH}\right), 16.7\left(\mathrm{CH}_{2} \mathrm{CH}_{3}\right) \mathrm{ppm}$; HRESIMS $(\mathrm{m} / \mathrm{z})$ : $[\mathrm{M}]^{+}$calcd for $\mathrm{C}_{18} \mathrm{H}_{21} \mathrm{~N}_{2} \mathrm{O}_{3}, 313.1547$; found, 313.1563 .

Diethyl 2-hydroxy-2-(2-oxo-1-phenylethyl)malonate (2a) was prepared according to the reported procedure [54] and obtained as orange oil. The synthesis was carried out twice, once using L-proline (82\%), once using 1 as catalyst (79\%).

Diethyl 2-hydroxy-2-(1-oxobutan-2-yl)malonate (2b) was prepared according to the reported procedure [54] and obtained as orange oil (using L-proline: $83 \%$, using 1: $80 \%$ ).

Crystal structure determination: $X$-ray crystallographic analysis of 7 was performed on a Nonius KappaCCD diffractometer using graphite monochromated Mo $\mathrm{K} \alpha$ radiation $(\lambda=0.71073 \AA)$. Intensities were measured by fine-slicing $\varphi$ and $\omega$-scans and corrected for background, polarization and Lorentz effects. A semi-empirical absorption correction was applied for the data sets following Blessing's method [61]. The structure was solved by direct methods and refined anisotropically by the least squares procedure implemented in the ShelX program system [62]. The hydrogen atoms were included isotropically using the riding model on the carbon atoms. Selected data: Crystal dimensions $0.36 \times 0.20 \times 0.11 \mathrm{~mm}^{3}$, $\mathrm{C}_{15} \mathrm{H}_{27} \mathrm{NO}_{7} \mathrm{~S}, M=365.4424$, orthorhombic, space group $P 2{ }_{1} 2{ }_{1}{ }_{1}, a=7.44860(10), b=8.94580(10), c=28.7024(4) \AA$, $\alpha=90^{\circ}, \beta=90^{\circ}, \gamma=90^{\circ}, V=1912.55(4) \AA^{3}, Z=4, \rho=1.269 \mathrm{~g}$ $\mathrm{cm}^{-3}, \mu=0.203 \mathrm{~mm}^{-1}, \mathrm{~F}(000)=748,18641$ reflections $\left(2 \theta_{\max }=27.99^{\circ}\right)$ measured (4566 unique, $R_{\text {int }}=0.0606$, completeness $=99.4 \%), R(I>2 \sigma(I))=0.0708, w R_{2}($ all data $)=$ 0.2054 . $\mathrm{GOF}=1.052$ for 224 parameters and 14 restraints, largest diff. peak and hole $1.557 /-0.438$ e $\AA^{3}$. CCDC-1016532 
contains the supplementary data for this structure. These data can be obtained free of charge from http://www.ccdc.cam.ac.uk/ data request/cif.

\section{Mass spectrometry}

ESI mass spectra were recorded on a Bruker APEX IV Fouriertransform ion cyclotron resonance (FT-ICR) mass spectrometer with a 7.05 T magnet and an Apollo electrospray (ESI) ion source equipped with an off-axis $70^{\circ}$ spray needle. Analyte solutions were fed into high pressure PEEK mixing tees from Alltech and then introduced into the ion source with a singleand a dual syringe pump from Cole Parmer and KD Scientific, respectively, at flow rates of $50 \mu \mathrm{L} / \mathrm{h}$ to $16 \mathrm{~mL} / \mathrm{h}$. The continuous-flow experiments were performed with a setup of two mixing tees. The first one was used for mixing a solution of both butyraldehyde and diethyl ketomalonate (each $2 \mathrm{mmol} / \mathrm{L}$ ) with a solution of the catalyst $(1 \mathrm{mmol} / \mathrm{L})$ and the second mixing tee served for sufficient dilution. Different reaction times were achieved by changing either the length of the capillary connecting both tees or by varying the flow rate. The theoretical reaction time between $\mathbf{1}$ and the reactants has been calculated from the experimental flow rates considering the volumes of both mixing tees and the connecting capillaries and under the assumption that the dilution in the second mixing tee decreases the reaction rate in the fashion of a bimolecular elementary reaction. For longer reaction times ( $>200 \mathrm{~s})$, the results can be compared with the ones from simple ESI measurements recorded at various times after offline mixing of the reaction partners. The results from both techniques match reasonably well, even though the reaction times calculated for the continous-flow setup seem to be slightly underestimated.

Ionization parameters were adjusted as follows: capillary voltage: -2.380 to $-3.800 \mathrm{~V}$; end plate voltage -2300 to $3320 \mathrm{~V}$; capexit voltage: 50 to $100 \mathrm{~V}$; skimmer voltages: 7 to $17 \mathrm{~V}$; temperature of drying gas: 50 to $80{ }^{\circ} \mathrm{C}$. Nitrogen was used as nebulizing (1.38 to 4.14 bar) and drying gas (1.38 to 3.10 bar). The ions were accumulated in the instruments hexapole for 0.3 to $0.9 \mathrm{~s}$, introduced into the FT-ICR cell which was operated at pressures below $10^{-10} \mathrm{mbar}$, and detected by a standard excitation and detection sequence. Collision-induced fragmentation was performed by on-resonance excitation with argon gas pulsed into the ICR cell followed by a pumping delay of 3-5 s. For each measurement, 8 to 64 scans were averaged. All signal assignments are based on exact mass determinations.

\section{Acknowledgements}

Financial support from the DFG (SFB 624 "templates") is gratefully acknowledged. We thank Charlotte Rödde and Dr.
Gregor Schnakenburg for the X-ray structure determination and Prof. A. C. Filippou for providing X-ray infrastructure.

\section{References}

1. Fenn, J. B. Angew. Chem., Int. Ed. 2003, 42, 3871-3894. doi:10.1002/anie.200300605

2. Cole, B., Ed. Electrospray Ionization Mass Spectrometry; Wiley: New York, 1997.

3. Schröder, D. Acc. Chem. Res. 2012, 45, 1521-1532. doi:10.1021/ar3000426

4. Eberlin, M. N. Eur. J. Mass Spectrom. 2007, 13, 19-28. doi:10.1255/ejms.837

5. Santos, L. S.; Knaack, L.; Metzger, J. O. Int. J. Mass Spectrom. 2005, 246, 84-104. doi:10.1016/j.ijms.2005.08.016

6. Chen, P. Angew. Chem. 2003, 115, 2938-2954 doi:10.1002/ange.200200560

7. Plattner, D. A. Top. Curr. Chem. 2003, 225, 153-203. doi:10.1007/3-540-36113-8_5

8. Vikse, K. L.; Ahmadi, Z.; Manning, C. C.; Harrington, D. A.; Mclndoe, J. S. Angew. Chem. 2011, 123, 8454-8456. doi:10.1002/ange.201102630

9. Adlhart, C.; Chen, P. Helv. Chim. Acta 2000, 83, 2192-2196. doi:10.1002/1522-2675(20000906)83:9<2192::AID-HLCA2192>3.0.CO ;2-G

10. Oliveira, F. F. D.; dos Santos, M. R.; Lalli, P. M.; Schmidt, E. M.; Bakuzis, P.; Lapis, A. A. M.; Monteiro, A. L.; Eberlin, M. N.; Neto, B. A. D. J. Org. Chem. 2011, 76, 10140-10147. doi:10.1021/jo201990n

11. Vikse, K. L.; Henderson, M. A.; Oliver, A. G.; Mclndoe, J. S. Chem. Commun. 2010, 46, 7412-7414. doi:10.1039/c0cc02773a

12. Schade, M. A.; Fleckenstein, J. E.; Knochel, P.; Koszinowski, K. J. Org. Chem. 2010, 75, 6848-6857. doi:10.1021/jo101337a

13. Thiery, E.; Chevrin, C.; Le Bras, J.; Harakat, D.; Muzart, J. J. Org. Chem. 2007, 72, 1859-1862. doi:10.1021/jo062491x 14. Santos, L. S.; Rosso, G. B.; Pilli, R. A.; Eberlin, M. N. J. Org. Chem. 2007, 72, 5809-5812. doi:10.1021/jo062512n

15. Enquist, P.-A.; Nilsson, P.; Sjöberg, P.; Larhed, M. J. Org. Chem. 2006, 71, 8779-8786. doi:10.1021/jo061437d

16. Sabino, A. A.; Machado, A. H. L.; Correia, C. R. D.; Eberlin, M. N. Angew. Chem. 2004, 116, 2568-2572. doi:10.1002/ange.200353076

17. Aliprantis, A. O.; Canary, J. W. J. Am. Chem. Soc. 1994, 116, 6985-6986. doi:10.1021/ja00094a083

18. Teichert, A.; Pfaltz, A. Angew. Chem. 2008, 120, 3408-3410. doi:10.1002/ange.200705082

19. Fürmeier, S.; Metzger, J. O. J. Am. Chem. Soc. 2004, 126, 14485-14492. doi:10.1021/ja046157z

20. Marquez, C. A.; Metzger, J. O. Chem. Commun. 2006, 1539-1541. doi:10.1039/b518288c

21. Cech, N. B.; Enke, C. G. Mass Spectrom. Rev. 2001, 20, 362-387. doi:10.1002/mas.10008

22. Chisholm, D. M.; Mclndoe, J. S. Dalton Trans. 2008, 3933-3945. doi:10.1039/b800371h

23. Smith, R. L.; Kenttämaa, H. I. J. Am. Chem. Soc. 1995, 117, 1393-1396. doi:10.1021/ja00109a025

24. Berkessel, A.; Gröger, H., Eds. Asymmetric Organocatalysis; Wiley-VCH: Weinheim, 2005. doi:10.1002/3527604677

25. Dalko, P., Ed. Enantioselective Organocatalysis; Wiley-VCH: Weinheim, 2007. doi:10.1002/9783527610945 
26. MacMillan, D. W. C. Nature 2008, 455, 304-308. doi:10.1038/nature07367

27. Melchiorre, P.; Marigo, M.; Carlone, A.; Bartoli, G. Angew. Chem. 2008, 120, 6232-6265. doi:10.1002/ange.200705523

28. Mukherjee, S.; Yang, J. W.; Hoffmann, S.; List, B. Chem. Rev. 2007, 107, 5471-5569. doi:10.1021/cr0684016

29. Dalko, P. I.; Moisan, L. Angew. Chem. 2004, 116, 5248-5286. doi:10.1002/ange.200400650

30. Notz, W.; Tanaka, F.; Barbas, C. F., III. Acc. Chem. Res. 2004, 37, 580-591. doi:10.1021/ar0300468

31. Schmid, M. B.; Zeitler, K.; Gschwind, R. M. Angew. Chem. 2010, 122, 5117-5123. doi:10.1002/ange.200906629 Angew. Chem., Int. Ed. 2010, 49, 4997-5003. doi:10.1002/anie.200906629

32. Dinér, P.; Kjærsgaard, A.; Lie, M. A.; Jørgensen, K. A. Chem. - Eur. J. 2007, 14, 122-127. doi:10.1002/chem.200701244

33. Zotova, N.; Franzke, A.; Armstrong, A.; Blackmond, D. G. J. Am. Chem. Soc. 2007, 129, 15100-15101. doi:10.1021/ja0738881

34. Mathew, S. P.; Klussmann, M.; Iwamura, H.; Wells, D. H., Jr.; Armstrong, A.; Blackmond, D. G. Chem. Commun. 2006, 4291-4293. doi:10.1039/b609926b

35. Iwamura, H.; Wells, D. H., Jr.; Mathew, S. P.; Klussmann, M.; Armstrong, A.; Blackmond, D. G. J. Am. Chem. Soc. 2004, 126, 16312-16313. doi:10.1021/ja0444177

36. Allemann, C.; Gordillo, R.; Clemente, F. R.; Cheong, P. H.-Y.; Houk, K. N. Acc. Chem. Res. 2004, 37, 558-569. doi:10.1021/ar0300524

37. List, B.; Hoang, L.; Martin, H. J. Proc. Natl. Acad. Sci. U. S. A. 2004, 101, 5839-5842. doi:10.1073/pnas.0307979101

38. Hoang, L.; Bahmanyar, S.; Houk, K. N.; List, B. J. Am. Chem. Soc. 2003, 125, 16-17. doi:10.1021/ja028634o

39. Bächle, F.; Duschmalé, J.; Ebner, C.; Pfaltz, A.; Wennemers, H. Angew. Chem. 2013, 125, 12851-12855. doi:10.1002/ange.201305338

40. Regiani, T.; Santos, V. G.; Godoi, M. N.; Vaz, B. G.; Eberlin, M. N.; Coelho, F. Chem. Commun. 2011, 47, 6593-6595. doi:10.1039/c1cc10678c

41. Beel, R.; Kobialka, S.; Schmidt, M. L.; Engeser, M. Chem. Commun. 2011, 47, 3293-3295. doi:10.1039/c0cc05347c

42. Alachraf, M. W.; Handayani, P. P.; Hüttl, M. R. M.; Grondal, C.; Enders, D.; Schrader, W. Org. Biomol. Chem. 2011, 9, 1047-1053. doi:10.1039/c003433a

43. Maltsev, O. V.; Chizhov, A. O.; Zlotin, S. G. Chem. - Eur. J. 2011, 17, 6109-6117. doi:10.1002/chem.201100388

44. Amarante, G. W.; Benassi, M.; Milagre, H. M. S.; Braga, A. A. C.; Maseras, F.; Eberlin, M. N.; Coelho, F. Chem. - Eur. J. 2009, 15, 12460-12469. doi:10.1002/chem.200900966

45. Schrader, W.; Handayani, P. P.; Zhou, J.; List, B. Angew. Chem. 2009, 121, 1491-1494. doi:10.1002/ange.200804353

46. Schrader, W.; Handayani, P. P.; Burstein, C.; Glorius, F. Chem. Commun. 2007, 716-718. doi:10.1039/b613862d

47. Milagre, C. D. F.; Milagre, H. M. S.; Santos, L. S.; Lopes, M. L. A.; Moran, P. J. S.; Eberlin, M. N.; Rodrigues, J. A. R. J. Mass Spectrom. 2007, 42, 1287-1293. doi:10.1002/jms.1173

48. Marquez, C. A.; Fabbretti, F.; Metzger, J. O. Angew. Chem. 2007, 119, 7040-7042. doi:10.1002/ange.200700266

49. Santos, L. S.; Pavam, C. H.; Almeida, W. P.; Coelho, F.; Eberlin, M. N. Angew. Chem. 2004, 116, 4430-4433. doi:10.1002/ange.200460059

50. List, B.; Lerner, R. A.; Barbas, C. F., III. J. Am. Chem. Soc. 2000, 122, 2395-2396. doi:10.1021/ja994280y
51. Machajewski, T. D.; Wong, C.-H. Angew. Chem. 2000, 112, 1406-1430.

doi:10.1002/(SICI)1521-3757(20000417)112:8<1406::AID-ANGE1406> 3.0.CO;2-R

Angew. Chem., Int. Ed. 2000, 39, 1352-1375.

doi:10.1002/(SICI)1521-3773(20000417)39:8<1352::AID-ANIE1352>3. $0 . \mathrm{CO} ; 2-\mathrm{J}$

52. Seebach, D.; Beck, A. K.; Badine, D. M.; Limbach, M.; Eschenmoser, A.; Treasurywala, A. M.; Hobi, R.; Prikoszovich, W.; Linder, B. Helv. Chim. Acta 2007, 90, 425-471. doi:10.1002/hlca.200790050

53. Bottoni, A.; Lombardo, M.; Miscione, G. P.; Montroni, E.; Quintavalla, A.; Trombini, C. ChemCatChem 2013, 5, 2913-2924. doi:10.1002/cctc.201300399

54. Bøgevig, A.; Kumaragurubaran, N.; Jørgensen, K. A. Chem. Commun. 2002, 620-621. doi:10.1039/b200681b

55. Diemer, V.; Chaumeil, H.; Defoin, A.; Fort, A.; Boeglin, A.; Carré, C. Eur. J. Org. Chem. 2006, 2727-2738. doi:10.1002/ejoc.200600030

56. Gu, W.; She, X.; Pan, X.; Yang, T.-K. Tetrahedron: Asymmetry 1998, 9 , 1377-1380. doi:10.1016/S0957-4166(98)00118-9

57. Chabaud, P.; Pèpe, G.; Courcambeck, J.; Camplo, M. Tetrahedron 2005, 61, 3725-3731. doi:10.1016/j.tet.2005.02.006

58. Tanaka, K.; Sawanishi, H. Tetrahedron: Asymmetry 1998, 9, 71-77. doi:10.1016/S0957-4166(97)00594-6

59. Cotton, R.; Johnstone, A. N.; North, M. Tetrahedron Lett. 1994, 35, 8859-8862. doi:10.1016/S0040-4039(00)78517-0

60. Pícha, J.; Vanek, V.; Buděšínský, M.; Mládková, J.; Garrow, T. A.; Jiráček, J. Eur. J. Med. Chem. 2013, 65, 256-275. doi:10.1016/j.ejmech.2013.04.039

61. Blessing, R. H. Acta Crystallogr., Sect. A 1995, 51, 33-38. doi:10.1107/S0108767394005726

62. Sheldrick, G. M. SHELXS97 and SHELXL97, University of Göttingen, Germany, 1997.

\section{License and Terms}

This is an Open Access article under the terms of the Creative Commons Attribution License (http://creativecommons.org/licenses/by/2.0), which permits unrestricted use, distribution, and reproduction in any medium, provided the original work is properly cited.

The license is subject to the Beilstein Journal of Organic Chemistry terms and conditions:

(http://www.beilstein-journals.org/bjoc)

The definitive version of this article is the electronic one which can be found at: $\underline{\text { doi:10.3762/bjoc. } 10.211}$ 